\title{
Prevalence of serological markers for hepatitis and potential associated factors in patients with diabetes mellitus
}

\author{
Clarissa Cordeiro Alves Arrelias ${ }^{1}$ \\ Fernando Belissimo Rodrigues ${ }^{2}$ \\ Maria Teresa da Costa Gonçalves Torquato ${ }^{3}$ \\ Carla Regina de Souza Teixeira ${ }^{4}$ \\ Flávia Fernanda Luchetti Rodrigues ${ }^{4}$ \\ Maria Lucia Zanetti ${ }^{4}$
}

\begin{abstract}
Objective: to estimate the prevalence of serological markers for hepatitis $B$ and $C$ in patients with diabetes mellitus and analyze potential associated factors. Method: a cross-sectional study with 255 patients with diabetes mellitus. Demographic, clinical, and risk behavior factors for hepatitis $B$ and $\mathrm{C}$ were selected. The markers HBsAg, Anti-HBc IgG, Anti-HBc IgM, Anti-HBs, and Anti-HCV were investigated. A questionnaire and venous blood collection and inferential statistical analysis were used. Results: $16.8 \%$ of the patients had a total reactive Anti-HBc marker, $8.2 \%$ an isolated Anti-HBs, and 75\% were non-reactive for all hepatitis B markers. No case of reactive HBsAg was found and $3.3 \%$ of the patients had a reactive anti-HCV marker. The prevalence of prior hepatitis $B$ virus infection was directly associated with the time of diabetes mellitus and the prevalence of hepatitis $C$ virus infection was not associated with the investigated variables. The prevalence of hepatitis $B$ and $C$ infection in patients with diabetes mellitus was higher when compared to the national, with values of $16.8 \%$ and $3.3 \%$, respectively. Conclusion: the results suggest that patients with diabetes are a population of higher vulnerability to hepatitis B and C, leading to the adoption of preventive measures of their occurrence.
\end{abstract}

Descriptors: Diabetes Mellitus; Hepatitis B; Hepatitis C; Immunization Coverage; Liver Diseases; Nursing.

\footnotetext{
Paper extracted from doctoral dissertation, "Prevalence of serological markers for hepatitis B and C and potential risk factors in patients with diabetes mellitus at a Basic Health District Unit", presented to Escola de Enfermagem de Ribeirão Preto, Universidade de São Paulo, PAHO/ WHO Collaborating Centre for Nursing Research Development, Ribeirão Preto, SP, Brazil.

1 Universidade de São Paulo, Hospital das Clinicas, Faculdade de Medicina de Ribeirão Preto, Ribeirão Preto, SP, Brazil.

2 Universidade de São Paulo, Faculdade de Medicina de Ribeirão Preto, Ribeirão Preto, SP, Brazil.

3 Prefeitura Municipal de Ribeirão Preto, Secretaria Municipal de Saúde, Ribeirão Preto, SP, Brazil.

${ }^{4}$ Universidade de São Paulo, Escola de Enfermagem de Ribeirão Preto, PAHO/WHO Collaborating Centre for Nursing Research Development, Ribeirão Preto, SP, Brazil.
}

\section{How to cite this article}

Arrelias CCA, Rodrigues FB, Torquato MTCG, Teixeira CRS, Rodrigues FFL, Zanetti ML. Prevalence of serological markersforhepatitisand potentialassociatedfactorsin patientswith diabetesmellitus. Rev. Latino-Am. Enfermagem. 2018;26:e3085.

[Access ]; Available in: DOI: http://dx.doi.org/10.1590/1518-8345.2774.3085. 


\section{Introduction}

The international literature shows outbreaks of hepatitis B virus (HBV) and hepatitis C virus (HCV) infection in the hospital, outpatient, and long-term care facilities. Infection cases have been shown to be more frequent in patients with diabetes mellitus (DM) than in those without the disease, suggesting that patients with DM are potentially more susceptible to HBV and HCV infection as a result of treatment and control procedures of the disease, in particular, the monitoring of capillary glycemia(1-8).

These outbreaks occur when infection control standards during capillary glycemia monitoring are neglected, such as the sharing of lancet pens, lancets, and glucometers without the proper disinfection process due to the transmission of microorganisms through the blood. HBV and HCV can survive on surfaces such as lancet pens, lancets, and glucometers on average for five to seven days, even in the absence of visible blood. During this period, the virus can cause infection if it reaches the bloodstream of a susceptible person ${ }^{(9-10)}$.

There is evidence that the severity and lethality related to $\mathrm{HBV}$ and $\mathrm{HCV}$ infection are higher in patients with DM than in those without the disease. Studies show that in patients infected with HBV and HCV, the presence of DM can accelerate the progression of liver disease, lead to cirrhosis, hepatocellular carcinoma, and death ${ }^{(11-12)}$. In addition, HBV and HCV infection may negatively influence the glycemic control of patients with DM, increasing the risk of hyperglycemia(13-15).

However, in Brazil, there is a shortage of studies regarding the behavior of hepatitis $B$ and $C$ in patients with DM. Regarding hepatitis C, four studies were identified in patients with $\mathrm{DM}^{(16-18)}$. One of them showed a high prevalence of hepatitis $C$ in patients with type 2 diabetes mellitus (DM2) when compared to blood donors without $\mathrm{DM}^{(16)}$. Another study also found a high prevalence of hepatitis $C$ in patients with $\mathrm{DM} 2^{(18)}$. On the other hand, studies did not identify a difference in the prevalence of hepatitis $C$ in patients with and without $\mathrm{DM}^{(14)}$ and cases of hepatitis $C$ in investigated patients with $D M 2^{(17)}$.

A study on the occurrence of hepatitis showed the magnitude of the prevalence of Hepatitis A, B, and C Virus Infections in the Brazilian macro-regions and represented a major step in coping with hepatitis in Brazil(19). However, the behavior of the disease in individuals with DM and risk factors related to infection in this population is unknown.

Thus, considering the significant increase in the prevalence of DM in the city of Ribeirão Preto, SP, Brazil, from $12.1 \%$ in 1997 to $15.1 \%$ in 2006 , the impact of HBV and HCV infection on morbidity and mortality, aggravated by DM, that patients with DM constitute an increased risk population for hepatitis $B$ and $C$, this study aimed to estimate the prevalence of serological markers for hepatitis $B$ and $C$ in patients with DM and analyze potential related risk factors. We believe that the proposed study can provide subsidies to know the magnitude of the problem and to advance the production of knowledge about hepatitis $B$ and $C$ and DM. This study may represent the emergence of a new research topic that could lead to other studies, translating into the quality of health information and, therefore, an improvement in the healthcare network.

\section{Method}

This is a cross-sectional study carried out in a secondary health unit in of a city in the State of São Paulo, Brazil. The study population consisted of 314 patients with type 1 and $2 \mathrm{DM}$, who attended at least one consultation in the period from July to December 2014. All patients of both sexes, aged 18 years or more, with a diagnosis of type 1 and 2 DM registered in the health records, and who attended the medical consultation from July to December 2014 were considered as eligible. Seven patients were excluded due to hearing or cognitive limitations that made it impossible to answer the questions of the instrument, and other 17 due to the difficulty of establishing contact by the researcher. Thus, 290 patients with DM were invited to participate in the study, of whom 35 refused. The main reasons cited for the refusal were the lack of time to answer the questionnaire, lack of interest in participating in the study because they had already participated in other research projects, and unavailability for blood collection. The convenience sample consisted of 255 patients with DM who attended the medical consultation during the data collection period and met the inclusion criteria. This value $(n=255)$ represents $88 \%$ of the patients invited to participate in the study, $81 \%$ of the study population and $39 \%$ of the patients with DM attended in that unit in 2014. The explanatory variables were demographic (sex, age, and schooling) and clinical (DM time, insulin use, capillary glycemia monitoring, medical, surgical, diagnostic, and therapeutic interventions, behaviors and situations of risk for hepatitis B and C), and the outcomes were HBV and HCV infection.

For this study, the researcher elaborated the questionnaire Occurrence of Serological Markers for Hepatitis B and C in Patients with Diabetes Mellitus based on the questionnaire for adolescents and adults used in the National Survey of Prevalence of Hepatitis A, B and C Virus Infections ${ }^{(20)}$, the researcher's experience with patients with $\mathrm{DM}$, and an extensive literature review on the subject(7-8,19-23). The questionnaire was composed of 96 questions subdivided into five parts: Identification (11 questions); Demographic variables (four questions); Clinical variables (51 questions); Behavioral variables (24 questions); and Results of serology tests for hepatitis B and C (six questions). 
The data collection instrument was pre-tested with ten patients in order to identify possible adjustments in the sequence of questions, test the approach to the patient, as well as estimate the time of application of the questionnaire. For data collection, the researcher had the collaboration of a student of Scientific Initiation previously qualified in order to standardize it. After the application of the pre-test, the questionnaire was maintained with no need for adjustments regarding its form and content. The ten patients were included in the final study sample. The data collection was carried out from July to December 2014.

Among the 255 patients, 226 attended the unit to collect blood, 19 performed the collection at home, and 10 patients refused to collect blood. Thus, 245 patients performed blood collection. The main reasons for the refusal were the lack of time and the withdrawal from participation in this phase of data collection.

The statistical analysis of the data was performed using the program STATA 11.0 (StataCorp LP, College Station, USA). The description of demographic and clinical data was presented through descriptive statistics, considering all the patients who participated in the study $(n=255)$. The serological analysis for hepatitis $B$ in patients who underwent blood sampling $(n=245)$ enabled to evaluate the presence of the markers HBsAg, Anti-HBc IgG, Anti-HBc IgM, e Anti-HBs. Because the markers HBsAg and Anti-HBc IgM were nonreactive for all patients for analysis and data presentation, the marker total Anti-HBc was considered as equivalent to Anti-HBc IgG. The serological analysis for hepatitis C allowed evaluating the presence of the marker Anti-HCV. A reactive result for this marker was considered an $\mathrm{HCV}$ infection. The univariate analysis of possible associations between demographic and clinical variables and HBV and HCV infection was determined by the Pearson-corrected chi-square test or two-tailed Fisher exact test and Wilcoxon test. The project was approved by the Research Ethics Committee under No. CAAE 24638213.2.0000.5393.

\section{Results}

The demographic and clinical characteristics of the $255(100 \%)$ investigated patients are described in Table 1.

Among the 245 (100\%) patients who attended the blood collection, $41(16.8 \%)$ presented a marker corresponding to prior infection with a spontaneous cure, $20(8.2 \%)$ presented vaccination seroconversion and, 184 (75\%) presented susceptibility to infection. No cases of acute or chronic hepatitis B were found. Therefore, the prevalence of prior HBV infection found in patients with DM was $16.8 \%$.

Table 2 shows the results obtained from the univariate analysis of prior $\mathrm{HBV}$ infection according to demographic and clinical variables. The prior infection had a direct association with age $(p=0.014)$ and DM time $(p=0.043)$. No significant association was observed for the other variables.
Table 3 shows the univariate analysis of prior infection according to variables related to the history of medical, surgical, diagnostic, and therapeutic interventions and situations and behaviors of risk for hepatitis $B$. The results show an association between prior infection and report of home contact with case of hepatitis $B(p=0.001)$, work as a police officer $(p=0.016)$, and higher number of sexual partners throughout life $(p=0.004)$.

The explanatory variables included in the logistic regression analysis were those that showed a possible association with the outcome $(p \leq 0.20)$. Among the variables included in the model, disease duration remained directly associated with the prior infection after the multivariate analysis, in which the DM time increases the risk of hepatitis B in approximately $4 \%$ each year of diagnosis of the disease. In addition, the work as a police officer was associated with infection (Table 4).

Among the 245 investigated patients, 8 (3.3\%) presented a reactive anti-HCV marker. Therefore, the prevalence of HCV infection found in patients with DM was 3.3\%. No significant association was found between the investigated demographic and clinical variables and HCV infection.

Table 1 - Distribution of patients with DM* according to demographic and clinical variables. Ribeirão Preto, SP, Brazil, 2014

\begin{tabular}{|c|c|c|}
\hline Demographic variables & $\mathbf{n}$ & $\%$ \\
\hline \multicolumn{3}{|l|}{ Gender } \\
\hline Male & 85 & 33.3 \\
\hline Female & 170 & 66.7 \\
\hline \multicolumn{3}{|l|}{ Age } \\
\hline Median (p25-p75) & \multicolumn{2}{|c|}{$63(55-71)$} \\
\hline \multicolumn{3}{|l|}{ Schooling } \\
\hline Illiterate & 9 & 3.5 \\
\hline Adult literacy & 2 & 0.8 \\
\hline Incomplete 1st to 4th grade of Elementary School & 51 & 20.0 \\
\hline Complete 1 st to 4 th grade of Elementary School & 69 & 27.1 \\
\hline Incomplete 5th to 8th grade of Elementary School & 26 & 10.2 \\
\hline Complete 5th to 8th grade of Elementary School & 31 & 12.2 \\
\hline Incomplete High School & 8 & 3.1 \\
\hline Complete High School & 39 & 15.3 \\
\hline Incomplete Higher Education & 10 & 3.9 \\
\hline Complete Higher Education & 10 & 3.9 \\
\hline \multicolumn{3}{|l|}{ Time of DM* (years) } \\
\hline Median (p25-p75) & \multicolumn{2}{|c|}{$10(4-20)$} \\
\hline \multicolumn{3}{|l|}{ Use de insulin } \\
\hline No & 105 & 41.2 \\
\hline Yes & 150 & 58.8 \\
\hline \multicolumn{3}{|l|}{ Monitoring of capillary glycemia } \\
\hline No & 65 & 25.5 \\
\hline Yes & 190 & 74.5 \\
\hline
\end{tabular}


Table 2 - Distribution of patients with DM* with and without prior hepatitis $B$ according to demographic and clinical variables of DM*. Ribeirão Preto, SP, Brazil, 2014

\begin{tabular}{|c|c|c|c|c|c|}
\hline \multirow{3}{*}{ Variables } & \multicolumn{4}{|c|}{ Total Anti-HBc $^{\dagger}$} & \multirow{3}{*}{ p } \\
\hline & \multicolumn{2}{|c|}{$(-)$} & \multicolumn{2}{|c|}{$(+)$} & \\
\hline & $\mathrm{n}$ & $\%$ & $\mathrm{n}$ & $\%$ & \\
\hline Total & 204 & 83.2 & 41 & 16.8 & \\
\hline \multicolumn{6}{|l|}{ Gender } \\
\hline Male & 63 & 30.9 & 17 & 41.5 & \\
\hline Female & 141 & 69.1 & 24 & 58.5 & $0.187^{\ddagger}$ \\
\hline \multicolumn{6}{|l|}{ Age } \\
\hline Median (p25-p75) & \multicolumn{2}{|c|}{$62.8(55.2-69.3)$} & \multicolumn{2}{|c|}{$68.4(58.9-75.2)$} & $0.014 \S$ \\
\hline \multicolumn{6}{|l|}{ Schooling } \\
\hline Illiterate & 6 & 2.9 & 3 & 7.3 & \\
\hline Adult literacy & 1 & 0.5 & 1 & 2.4 & \\
\hline $\begin{array}{l}\text { Incomplete 1st to } 4 \text { th } \\
\text { grade of Elementary } \\
\text { School }\end{array}$ & 40 & 19.6 & 9 & 22.0 & \\
\hline $\begin{array}{l}\text { Complete } 1 \text { st to } 4 \text { th } \\
\text { grade of Elementary } \\
\text { School }\end{array}$ & 57 & 28.0 & 8 & 19.5 & \\
\hline $\begin{array}{l}\text { Incomplete 5th to 8th } \\
\text { grade of Elementary } \\
\text { School }\end{array}$ & 19 & 9.3 & 6 & 14.6 & \\
\hline $\begin{array}{l}\text { Complete 5th to 8th } \\
\text { grade of Elementary } \\
\text { School }\end{array}$ & 25 & 12.3 & 4 & 9.8 & \\
\hline $\begin{array}{l}\text { Incomplete High } \\
\text { School }\end{array}$ & 8 & 3.9 & - & - & \\
\hline $\begin{array}{l}\text { Complete High } \\
\text { School }\end{array}$ & 31 & 15.2 & 7 & 17.1 & \\
\hline $\begin{array}{l}\text { Incomplete Higher } \\
\text { Education }\end{array}$ & 8 & 3.9 & 2 & 4.9 & \\
\hline $\begin{array}{l}\text { Complete Higher } \\
\text { Education }\end{array}$ & 9 & 4.4 & 1 & 2.4 & 0.5211 \\
\hline \multicolumn{6}{|l|}{ Time of DM" (years) } \\
\hline Median (p25-p75) & \multicolumn{2}{|c|}{$10(4-19)$} & \multicolumn{2}{|c|}{$12(10-23)$} & $0.043^{\prime \prime}$ \\
\hline \multicolumn{6}{|l|}{ Use of insulin } \\
\hline No & 82 & 40.2 & 19 & 46.3 & \\
\hline Yes & 122 & 59.8 & 22 & 53.7 & $0.466^{\ddagger}$ \\
\hline \multicolumn{6}{|c|}{ Monitoring of capillary glycemia } \\
\hline No & 51 & 25.0 & 10 & 24.4 & \\
\hline Yes & 153 & 75.0 & 31 & 75.6 & $0.934^{\ddagger}$ \\
\hline
\end{tabular}

*DM - Diabetes mellitus; †Anti-HBC - Antibody (IgM or IgG) against hepatitis B virus core antigen; $¥$ Pearson-corrected chi-square test; §Wilcoxon test; ||Two-tailed Fisher exact test
Table 3 - Distribution of patients with DM* with and without prior hepatitis B according to the history of medical, surgical, diagnostic, and therapeutic interventions and situations and behaviors of risk for hepatitis B. Ribeirão Preto, SP, Brazil, 2014

\begin{tabular}{|c|c|c|c|c|c|}
\hline \multirow{3}{*}{ Variables } & \multicolumn{4}{|c|}{ Total Anti-HBc $^{\dagger}$} & \multirow{3}{*}{$\mathbf{p}$} \\
\hline & \multicolumn{2}{|c|}{$(-)$} & \multicolumn{2}{|c|}{$(+)$} & \\
\hline & $\mathbf{n}$ & $\%$ & $\mathbf{n}$ & $\%$ & \\
\hline Total & 204 & 83.2 & 41 & 16.8 & \\
\hline \multicolumn{6}{|l|}{ History of interventions ${ }^{\ddagger}$} \\
\hline Hospitalization & 132 & 64.7 & 27 & 65.8 & $0.888^{\S}$ \\
\hline Surgery & 161 & 16.3 & 33 & 80.5 & $0.822^{\S}$ \\
\hline Blood/derivative transfusion & 40 & 19.6 & 4 & 9.8 & $0.181 "$ \\
\hline Dental treatment & 162 & 79.4 & 29 & 70.7 & $0.221^{\S}$ \\
\hline Endoscopy & 75 & 36.8 & 14 & 34.2 & $0.750^{\S}$ \\
\hline Hemodialysis & 3 & 1.5 & - & - & $1.000^{\prime \prime}$ \\
\hline \multicolumn{6}{|l|}{ Situations and behaviors of risk ${ }^{\ddagger}$} \\
\hline $\begin{array}{l}\text { Home contact with case of } \\
\text { hepatitis B }\end{array}$ & 3 & 1.5 & 6 & 14.6 & $0.001 "$ \\
\hline $\begin{array}{l}\text { Sexual contact with case of } \\
\text { hepatitis B }\end{array}$ & 1 & 0.5 & - & - & $1.000^{\prime \prime}$ \\
\hline Sharing of sharps & 84 & 41.2 & 13 & 31.7 & $0.258^{\prime \prime}$ \\
\hline Tattoo & 8 & 3.9 & 1 & 2.4 & $1.000^{\prime \prime}$ \\
\hline Piercing & 4 & 2.0 & - & - & $1.000^{\prime \prime}$ \\
\hline Health professional & 19 & 9.3 & 4 & 9.8 & $1.000^{\prime \prime}$ \\
\hline Work as a police officer & 1 & 0.5 & 3 & 7.3 & $0.016^{\ddagger}$ \\
\hline $\begin{array}{l}\text { Work as a penitentiary } \\
\text { agent/prison officer }\end{array}$ & 1 & 0.5 & - & - & $1.000^{\prime \prime}$ \\
\hline $\begin{array}{l}\text { Worker collecting } \\
\text { household/hospital waste }\end{array}$ & 7 & 3.4 & 1 & 2.4 & $1.000^{\prime \prime}$ \\
\hline $\begin{array}{l}\text { Work as a manicurist/ } \\
\text { chiropodist/podiatrist }\end{array}$ & 11 & 5.4 & 1 & 2.4 & $0.696 "$ \\
\hline Smoked drugs & 3 & 1.5 & 1 & 2.4 & $0.522 "$ \\
\hline Smelled drugs & 2 & 1.0 & 1 & 2.4 & $0.424^{\prime \prime}$ \\
\hline Condom use & 16 & 7.8 & 2 & 4.9 & $1.000^{\prime \prime}$ \\
\hline $\begin{array}{l}\text { Sexually transmitted } \\
\text { disease }\end{array}$ & 30 & 14.7 & 8 & 19.5 & $0.438^{\prime \prime}$ \\
\hline $\begin{array}{l}\text { Number of sexual partners } \\
\text { throughout life } \\
\text { Median (p25-p75) }\end{array}$ & \multicolumn{2}{|c|}{$1(1-3.5)$} & \multicolumn{2}{|c|}{$3(1-10)$} & $0.004 \pi$ \\
\hline \multicolumn{6}{|c|}{ Frequency of alcohol consumption (last three months) } \\
\hline None & 153 & 75.0 & 29 & 70.7 & \\
\hline Once a month & 19 & 9.3 & 4 & 9.8 & \\
\hline Two to three times a month & 15 & 7.4 & 3 & 7.3 & \\
\hline One to two days a week & 13 & 6.4 & 2 & 4.9 & \\
\hline Three to four days a week & 1 & 0.5 & 3 & 7.3 & \\
\hline Almost everyday & 2 & 1.0 & - & - & \\
\hline Every day & 1 & 0.5 & - & - & $0.202^{\ddagger}$ \\
\hline
\end{tabular}

Table 4 - Logistic regression model for prior hepatitis B. Ribeirão Preto, SP, Brazil, 2014

\begin{tabular}{lccc}
\hline \multicolumn{1}{c}{ Variables* $^{*}$} & $\mathrm{OR}^{\dagger}\left(\mathbf{9 5} \% \mathrm{Cl}^{\ddagger}\right)$ & $\mathrm{p}$ & Standard error \\
\hline Female & $0.74(0.32-1.71)$ & 0.487 & 0.31 \\
Age & $1.02(0.99-1.06)$ & 0.143 & 0.01 \\
Time of DM & $1.04(1.00-1.08)$ & 0.024 & 0.01 \\
Home contact hepatitis B & $0.97(0.85-1.10)$ & 0.658 & 0.06 \\
Work as a police officer & $13.82(1.27-149.94)$ & 0.031 & 16.81 \\
Sexual partners throughout life & $1.00(0.99-1.00)$ & 0.927 & 0.001 \\
Alcohol consumption & $1.04(0.75-1.44)$ & 0.806 & 0.17 \\
Blood/derivative transfusion & $0.55(0.17-1.72)$ & 0.309 & 0.32
\end{tabular}

*Those that showed $\mathrm{p} \leq 0.20$ in the univariate analysis were included. Each variable was adjusted for the other seven; + OR - Odds ratio; $\neq C I-C o n f i d e n c e$ interval; §DM - Diabetes mellitus 


\section{Discussion}

When comparing the obtained results with the population-based survey conducted in Brazil, the prevalence of HBV exposure (16.8\%) was higher than the national prevalence $(11.6 \%)$ in the general population from 20 to 69 years. Regarding the prevalence of acute or chronic infection, the prevalence found was lower than the national prevalence, with a value of $0.6 \%{ }^{(19)}$. This result suggests that the prevalence of HBV exposure is higher in individuals with DM when compared to those without the disease ${ }^{(5)}$.

The prevalence of prior cured infection and vaccine immunity marker were higher than in Spain ${ }^{(24)}$. On the other hand, studies carried out in Poland and Turkey showed two-fold higher values(25-27). Other studies also found a higher prevalence ${ }^{(16,25-29)}$.

The association of exposure to HBV and a longer time of DM can be interpreted as a cumulative risk of exposure to the virus probably attributed to the disease management since DM does not progress to hepatitis B or C. The association of exposure to HBV and a longer time of DM were reported in Poland(26), Turkey(28), and Nigeria( ${ }^{(30)}$. On the other hand, a study carried out in Italy found no association of infection and time of $\mathrm{DM}^{(27)}$.

In accordance with another study(27), the present study also did not find an association of HBV infection with demographic variables, variables related to insulin use, monitoring of capillary glycemia, and history of medical, surgical, diagnostic, and therapeutic interventions. In addition, the majority of the investigated patients monitored capillary glycemia at home and outbreaks of $\mathrm{HBV}$ infection reported in the literature were in institutionalized patients and health services undergoing assisted monitoring of capillary glycemia without proper infection control practices ${ }^{(1-2,4,6)}$

The prevalence of HCV infection was 3.3\% higher than the national prevalence for the general population from 20 to 69 years old, which was $1.6 \%(24,27)$, as well as national studies with specific populations such as the deaf, military males, and workers collecting household waste $^{(31-33)}$. On the other hand, a study that investigated the prevalence of $\mathrm{HCV}$ infection in elderly patients in southern Brazil found a prevalence of $2.2 \%{ }^{(34)}$.

The prevalence of hepatitis $C$ in patients investigated in our study was also higher than that found in three national studies with patients with $\mathrm{DM}^{(16-17)}$. The difference in the observed prevalence can be attributed to the composition of the sample regarding the age group. An old age is considered a risk factor for exposure to HCV infection (20-21). The time of DM found in these studies was also lower than that found in our study, which may also justify the difference in the observed prevalence.
On the other hand, a study carried out in southern Brazil showed that the prevalence was four times higher in patients with DM2 undergoing outpatient care ${ }^{(18)}$. The time of DM of the investigated outpatients is higher when compared to those of our study, which may have contributed to a higher prevalence of infection.

International studies investigating the prevalence of HCV exposure in patients with DM in an outpatient clinic or hospital found a lower ${ }^{(7,24,30)}$, $\operatorname{similar}^{(23,28)}$, and higher $(8,22,25,27,29)$ prevalence in relation to our results.

Since the 1990s studies have shown a higher prevalence of hepatitis $C$ in patients with DM when compared to those without this disease $\mathrm{e}^{(7-8,16,23,27)}$. When comparing the prevalence of hepatitis $\mathrm{C}$ in patients with DM found in our study (3.3\%) and the prevalence observed in the general Brazilian population $(1.4 \%)^{(19)}$, we also observed a higher prevalence of infection in patients with DM.

However, in our study, although we found a prevalence of HCV infection higher than that of the Brazilian population, we did not observe an association of HCV infection with demographic variables, variables related to insulin use, monitoring of capillary glycemia, and history of medical, surgical, diagnostic, and therapeutic interventions, which is in agreement with national studies(16-18).

Other studies reported in the international literature found as variables associated with infection only recognized risk factors for hepatitis $\mathrm{C}$ such as the history of blood transfusion, sharing of sharps, multiple sexual partners, and changes in liver enzyme levels ${ }^{(16,18,23,25,29)}$.

A study carried out in France found a significant difference in the prevalence of HCV infection in patients with $(3.1 \%)$ and without DM $(0.04 \%)$. However, the hypothesis that the type of treatment for DM, previous hospitalizations, and lancet use pen for monitoring the capillary glycemia are associated with HCV infection in patients with DM has not been confirmed( ${ }^{(35)}$.

These results lead to the assumption that HCV infection may present as a risk factor for the development of DM, as investigated in other studies ${ }^{(36-37)}$. Studies have shown that HCV infection is followed by defects in the insulin-signaling pathway in the liver, which may contribute to insulin resistance and $\mathrm{DM}^{(37)}$. However, $\mathrm{HCV}$-induced insulin resistance mechanisms are still partially understood ${ }^{(14,38)}$. Another study shows that liver inflammation is a possible risk factor for pre-diabetes in the context of HCV infection ${ }^{(39)}$.

In summary, when considering the higher prevalence of HBV exposure and its relation to the time of DM, it is suggested to deepen new investigations related to diabetes management that may contribute to HBV infection. The absence of association of HCV infection with the studied variables can be attributed to the relatively low number 
of infected individuals. This research is a pioneer in Brazil and offers subsidies for comparisons with future studies and advances in the knowledge of the subject.

This study offers subsidies to know the magnitude of the problem and advance the production of knowledge about hepatitis B and C and DM. The study can generate new research themes, translating into the quality of health information and, therefore, qualification of nursing care.

\section{Conclusion}

The prevalence of HBV infection in patients with DM was $16.8 \%$, which is higher than the national level and was directly associated with the time of DM. No cases of acute or chronic hepatitis B were found. The prevalence of $\mathrm{HCV}$ infection was $3.3 \%$, which is higher than the national level and had no association with the investigated demographic and clinical variables. Further studies need to be developed to investigate these issues and deepen the knowledge of the relationship between hepatitis $C$ and DM in the national population aiming at the timely adoption of preventive measures.

\section{References}

1. Bender TJ, Wise ME, Utah O, Moorman AC, Sharapov U, Drobeniuc J, et al. Outbreak of hepatitis B virus infections associated with assisted monitoring of blood glucose in an assisted living facility-Virginia, 2010. PLoS One. 2012; 7(12):e50012. doi: http://dx.doi.org/10.1371/journal. pone.0050012

2. Lanini S, Garbuglia AR, Puro V, Solmone M, Martini L, Arcese W, et al. Hospital cluster of HBV infection: Molecular evidence of patient-to-patient transmission through lancing device. PLoS One. 2012; 7(3):e33122. doi: http://dx.doi. org/10.1371/journal.pone.0033122

3. Reilly ML, Schillie SF, Smith E, Poissant T, Vonderwahl CW, Gerard K, et al. Increased Risk of Acute Hepatitis B among Adults with Diagnosed Diabetes Mellitus. J Diabetes Sci Technol. 2012; 6(4):858-66. doi: http:// dx.doi.org/10.1177/193229681200600417

4. Schaffzin JK, Southwick KL, Clement EJ, Konings F, Ganova-Raeva L, Xia G, et al. Transmission of hepatitis B virus associated with assisted monitoring of blood glucose at an assisted living facility in New York State. Am J Infect Control. 2012;40(8):726-31. doi: http://dx.doi. org/10.1016/j.ajic.2011.11.002

5. Schillie SF, Xing J, Murphy TV, Hu DJ. Prevalence of hepatitis $B$ virus infection among persons with diagnosed diabetes mellitus in the United States, 1999-2010. J Viral Hepatol. 2012; 19(9):674-6. doi: http://dx.doi. org/10.1111/j.1365-2893.2012.01616
6. Diercke M, Monazahian M, Petermann H, Gerlich WH, Schüttler CG, Wend $U$, et al. Hepatitis B outbreak in a nursing home associated with reusable lancet devices for blood glucose monitoring, Northern Germany 2010. J Med Virol. 2015; 87(4):583-8. doi: http://dx.doi.org/10.1002/ jmv. 24104

7. Ba-Essa EM, Mobarak EI, Al-Daghri NM. Hepatitis C virus infection among patients with diabetes mellitus in Dammam, Saudi Arabia. BMC Health Serv Res. 2016; 16:313. doi: http://dx.doi.org/10.1186/s12913-0161578-0

8. Kanwal N, Nasir B, Abrar MA, Kaukab I, Nawaz A, Nisar $N$, et al. Prevalence of hepatitis $C$ in diabetic patients: a prospective study. Acta Pol Pharm. [Internet]. 2016 [cited Jun 15, 2017]; 73(3):771-5. Available from: https:// www.ncbi.nlm.nih.gov/pubmed/27476296

9. Bond WW, Favero MS, Petersen NJ, Gravelle CR, Ebert JW, Maynard JE. Survival of hepatitis B virus after drying and storage for one week. Lancet. 1981; 1(8219):550-1. doi: http://dx.doi.org/10.1016/S01406736(81)92877-4

10. Doerrbecker J, Friesland M, Ciesek S, Erichsen TJ, Mateu-Gelabert P, Steinmann J, et al. Inactivation and survival of hepatitis $C$ virus in inanimate surfaces. J Infect Dis. 2011; 204(12):1830-8. doi: http://dx.doi. org/10.1093/infdis/jir535

11. Huang YW, Wang TC, Lin SC, Chang HY, Chen DS, Hu $\mathrm{JT}$, et al. Increased risk of cirrhosis and its decompensation in chronic hepatitis B patients with new onset diabetes: a nationwide cohort study. Clin Infect Dis. 2013; 57(12):1695-702. doi: http://dx.doi.org/10.1093/cid/ cit603

12. Doerrbecker J, Friesland M, Ciesek S, Erichsen TJ, Mateu-Gelabert $P$, Steinmann J. Type 2 diabetes: a risk factor for liver mortality and complications in hepatitis $B$ cirrhosis patients. J Infect Dis. 2011; 204(12):1830-8. doi: http://dx.doi.org/10.1093/infdis/jir535

13. Lecube A, Hernández C, Genescà J, Simó R. Glucose abnormalities in patients with hepatitis $C$ virus infection: epidemiology and pathogenesis. Diabetes Care. 2006; 29(5):1140-9. doi: https://dx.doi.org/10.2337/ diacare. 2951140

14. Gutiérrez-Grobe Y, Ponciano-Rodríguez G, MéndezSánchez N. Viral hepatitis infection and insulin resistance: a review of the pathophysiological mechanisms. Salud Publica Mex. [Internet]. 2011 [cited Jul 10, 2017]; 53Suppl1:S46-51. Available from: https://www.ncbi. nlm.nih.gov/pubmed/21877073

15. Gundling F, Seid $H$, Strassen I, Haller B, Siegmund T, Umgelter $A$, et al. Clinical manifestations and treatment options in patients with cirrhosis and diabetes mellitus. Digestion. 2013; 87(2):75-84. doi: http://dx.doi. org/10.1159/000343458 
16. Parolin MB, Réa R, Vargas RM, Almeida ACR, Baldanzi GR, Lopes RW. Prevalence of hepatitis C infection in patients with type 2 diabetes mellitus. Arq. Gastroenterol. 2006; 43(2): 77-80. doi: http://dx.doi.org/10.1590/ S0004-28032006000200003

17. Costa LMFC, Mussi ADH, Brianeze MR, Souto FJD. Hepatitis $C$ as a risk factor for diabetes type 2: lack of evidence in a hospital in central-west Brazil. Braz J Infect Dis. 2008; 12(1):24-26. doi: http://dx.doi.org/10.1590/ S1413-86702008000100007

18. Greca LF, Pinto LC, Rados DR, Canani LH, Gross JL. Clinical features of patients with type 2 diabetes mellitus and hepatitis C infection. Braz J Med Biol Res. 2012; 45(3):284-90. doi: http://dx.doi.org/10.1590/S0100879X2012007500013

19. Pereira LM, Martelli CM, Merchán-Hamann E, Montarroyos UR, Braga MC, Lima ML, et al. PopulationBased Multicentric Survey of Hepatitis B Infection and Risk Factor Differences among Three Regions in Brazil. Am J Trop Med Hyg. [Internet]. 2009 [cited Jun 15, 2017]; 81(2):240-7. Available from: https://www.ncbi.nlm.nih. gov/pubmed/19635877

20. Ximenes RAA, Pereira LMB, Martelli CMT, MerchánHamann E, Stein AT, Figueiredo GM, et al. Methodology of a nationwide cross-sectional survey of prevalence and epidemiological patterns of hepatitis $A, B$ and $C$ infection in Brazil. Cad Saúde Pública. 2010; 26(9):1693-704. doi: http://dx.doi.org/10.1590/S0102-311X2010000900003 21. Pereira LM, Martelli CM, Moreira RC, Merchan-Hamman E, Stein AT, Cardoso MR, et al. Prevalence and risk factors of Hepatitis C virus infection in Brazil, 2005 through 2009: a cross-sectional study. BMC Infect Dis. 2013; 13:60. doi: http://dx.doi.org/10.1186/1471-2334-13-60

22. Khan N, Khan N, Hussain J, Ullah H, Khan H. Frequency of hepatitis $\mathrm{C}$ in type 2 diabetic patients. Gomal J Med Sci. [Internet]. 2014 [cited Jan 20, 2018]; 12(2):81-3. Available from: http://www.gjms.com.pk/ojs24/index. php/gjms/article/view/1033/633

23. Korkmaz H, Kesli R, Pamuk BO, Ipekci SH, Terzi $Y$, Kebapcilar L. Assessment of evidence for positive association and seroprevalence of hepatitis $B$ and $C$ in diabetic patients in a developing country. J Investig Med. 2015; 63:251-7. doi: http://dx.doi.org/10.1097/ JIM.0000000000000126

24. Esparsa-Martín N, Hernández-Betancor A, SuriaGonzález S, Batista-García F, Braillard-Pocard P, SánchezSantana AY, et al. Serology for hepatitis B and C, HIV and syphilis in the initial evaluation of diabetes patients referred for an external nephrology consultation. Nefrologia. 2013; 33(1):124-7. doi: http://dx.doi.org/10.3265/Nefrologia. pre2012.Jul.11331

25. Ozyilkan E, Erbaş T, Simşek H, Telatar F, Kayhan $B$, Telatar $H$. Increased prevalence of hepatitis $C$ vírus antibodies in patients with diabetes mellitus. J Intern Med. 1994; 235(3):283-4. doi: http://dx.doi. org/10.1111/j.1365-2796.1994.tb01075

26. Halota W, Muszyńska M, Pawłowska M. Hepatitis B virus serologic markers and anti-hepatitis $B$ vaccination in patients with diabetes. Med Sci Monit. [Internet]. 2002 [cited Nov 26, 2017]; 8(7):516-9. Available from: https:// www.ncbi.nlm.nih.gov/pubmed/12118201

27. Sangiorgio L, Attardo T, Gangemi R, Rubino C, Barone $M$, Lunetta $M$. Increased frequency of HCV and HBV infection in type 2 diabetic patients. Diabetes Res Clin Pract. [Internet]. 2000 [cited Feb 11, 2017]; 48(2):14751. Available from: https://www.ncbi.nlm.nih.gov/ pubmed/10802152

28. Gulcan A, Gulcan E, Toker A, Bulut I, Akcan Y. Evaluation of risk factors and seroprevalence of hepatitis $B$ and $C$ in diabetic patients in Kutahya, Turkey. J Investig Med. 2008; 56(6):858-63. doi: http://dx.doi.org/10.2310/ JIM.0b013e3181788d28

29. Soverini V, Persico M, Bugianesi E, Forlani G, Salamone $\mathrm{F}$, Masarone M, et al. HBV and HCV infection in type 2 diabetes mellitus: a survey in three diabetes units in different Italian areas. Acta Diabetol. 2011; 48(4):33743. doi: http://dx.doi.org/10.1007/s00592-011-0293-x 30. Onyekwere CA, Ogbera AO, Dada AO, Adeleye OO, Dosunmu AO, Akinbami AA, et al. Hepatitis C Virus (HCV) Prevalence in Special Populations and Associated Risk Factors: A Report From a Tertiary Hospital. Hepat Mon. 2016; 16(5):e35532. doi: http://dx.doi.org/10.5812/ hepatmon.35532

31. Pacher BM, Costa MRB, Nascimento MMP, Moura MC, Passos ADC. Hepatitis $B$ and $C$ in a Brazilian deaf community. Rev Soc Bras Med Trop. 2015; 48(5):603-6. doi: http://dx.doi.org/10.1590/0037-8682-0058-2015 32. Villar LM, Ó KM, Scalioni LP, Cruz HM, Portilho MM, Mendonça $A C$, et al. Prevalence of hepatitis $B$ and $C$ virus infections among military personnel. Braz J Infect Dis. 2015; 19(3):285-90. doi: http://dx.doi.org/10.1016/j. bjid.2015.02.002

33. Mol MP, Gonçalves JP, Silva EA, Scarponi CF, Greco DB, Cairncross $S$, et al. Seroprevalence of hepatitis B and $\mathrm{C}$ among domestic and healthcare waste handlers in Belo Horizonte, Brazil. Waste Manag Res. 2016; 34(9):87583. doi: http://dx.doi.org/10.1177/0734242X16649686 34. Martins T, Machado DF, Schuelter-Trevisol F, Trevisol DJ, Vieira e Silva RA, Narciso-Schiavon JL, et al. Prevalence and factors associated with HCV infection among elderly individuals in a southern Brazilian city. Rev Soc Bras Med Trop. 2013; 46(3):281-7. doi: http://dx.doi. org/10.1590/0037-8682-0026-2013

35. Rudoni S, Petit JM, Bour JB, Aho LS, Castaneda A, Vaillant $\mathrm{G}$, et al. HCV infection and diabetes mellitus: influence of the use of finger stick devices on nosocomial 
transmission. Diabetes Metab. [Internet]. 1999 [cited Dec 8, 2017]; 25(6):502-5. Available from: https://www.ncbi. nlm.nih.gov/pubmed/10633875

36. White DL, Ratziu V, El-Serag HB. Hepatitis C infection and risk of diabetes: a systematic review and metaanalysis. J Hepatol. 2008; 49(5):831-44. doi: http:// dx.doi.org/10.1016/j.jhep.2008.08.006

37. Naing C, Mak JW, Ahmed SI, Maung M. Relationship between hepatitis $C$ virus infection and type 2 diabetes mellitus: meta-analysis. World J Gastroenterol. 2012; 18(14):1642-51. doi: http://dx.doi.org/10.3748/wjg. v18.i14.1642

38. Knobler $\mathrm{H}$, Malnick $\mathrm{S}$. Hepatitis $\mathrm{C}$ and insulin action: $\mathrm{An}$ intimate relationship. Wld J Hepatol. 2016; 8(2): 131-8. doi: http://dx.doi.org/10.4254/wjh.v8.i2.131

39. Burman BE, Bacchetti $P$, Ayala CE, Gelman N, Melgar J, Khalili M. Liver inflammation is a risk factor for prediabetes in at-risk latinos with and without hepatitis $C$ infection. Liver Int. 2015;35(1):101-7. doi: http://dx.doi.

org/10.1111/liv.12676 Creative Commons (CC BY).

This license lets others distribute, remix, tweak, and build upon your work, even commercially, as long as they credit you for the original creation. This is the most accommodating of licenses offered. Recommended for maximum dissemination and use of licensed materials. 